\title{
IDENTIFIKASI KAWASAN RAWAN KONVERSI PADA LAHAN SAWAH DI KECAMATAN 2 X 11 ENAM LINGKUNG KABUPATEN PADANG PARIAMAN BERBASIS GIS (GEOGRAPHIC INFORMATION SYSTEM)
}

\author{
Feri Arlius, Eri Gas Ekaputra, Ghani Tasrif \\ Fakultas Teknologi Pertanian, Kampus Limau Manis-Padang 25163 \\ Email: sipado@yahoo.com
}

\begin{abstract}
ABSTRAK
Lahan sawah Kecamatan 2x11 Enam Lingkung merupakan kawasan rawan konversi, hal ini dikarenakan wilayah Kecamatan 2x11 Enam Lingkung dilewati oleh jalan utama Padang- Bukittinggi dengan potensi terjadinya tingkat konversi lahan tinggi. Laju pertumbuhan penduduk setiap tahunnya meningkat dan letak daerah Kecamatan 2x11 Enam Lingkung berdekatan dengan pusat Kabupaten Padang Pariaman juga faktor yang mengakibatkan lahan sawah yang ada menjadi rawan konversi. Penelitian ini bertujuan untuk mengidentifikasi kawasan rawan konversi pada lahan sawah di Kecamatan 2x11 Enam Lingkung Kabupaten Padang Pariaman. Hasil pengolahan data spasial dan citra Kecamatan 2x11 Enam Lingkung diperoleh luas areal sawah untuk Kecamatan 2x1 Enam Lingkung tahun 2016 sebesar 886,66 Ha. Lahan sawah di Kecamatan 2x11 Enam Lingkung dibagi menjadi 4 kelas berdasarkan kriteria kualitas lahan sawah. Lahan sawah rawan konversi dibagi mejadi 4 tipe konversi lahan. Berdasarkan hasil pengolahan data didapatkan lahan rawan konversi pada lahan sawah di Kecamatan 2x11 Enam Lingkung seluas 185,83 Ha. Luas lahan sawah tipe konversi sistematik berpola enclave (K2) sebesar 55,81 Ha, tipe konversi lahan sebagai respon atas pertumbuhan penduduk (K3) sebesar 55,65 Ha, tipe konversi multi bentuk atau tanpa bentuk (K7) sebesar 2,22, dan tipe konversi kawasan jalan (K8) sebesar 72,15 Ha. Prediksi kehilangan produksi padi jika semua lahan sawah rawan konversi mengalami konversi lahan sebesar $\pm 1405,99$ Ton/Tahun

Kata kunci - lahan rawan konversi; lahan sawah; kriteria kualitas lahan; tipe konversi lahan
\end{abstract}

\section{PENDAHULUAN}

Lahan merupakan sumber daya pokok dalam pertanian yang mana memiliki sifat yang terbatas, baik kemampuan maupun ketersediaanya. Ketersediaan lahan yang sangat terbatas akan menimbulkan kelangkaan lahan dan konflik penggunaan lahan, sehingga mendorong terjadinya konversi lahan. Salah satu masalah konversi lahan adalah konversi lahan pertanian terutama lahan sawah menjadi penggunaan non pertanian. Konversi lahan adalah proses alih fungsi lahan khususnya dari lahan pertanian ke nonpertanian atau dari lahan non-pertanian ke lahan pertanian (Sihaloho, 2004). Konversi lahan pertanian ke non-pertanian mengalami laju yang tinggi untuk keperluan industri dan memenuhi kebutuhan pemukiman penduduk. Konversi lahan sawah menjadi penggunaan lahan lain seperti pemukiman dan industri merupakan kondisi aktual yang sulit dihindari karena merupakan tuntutan kebutuhan masyarakat akibat pertambahan jumlah penduduk dan peningkatan kegiatan sosial ekonomi.

Jika ditinjau dari segi kependudukannya maka jumlah penduduk Kabupaten Padang Pariaman pada tahun 2010 berjumlah 392.503 jiwa, sedangkan pada tahun 2014 berjumlah 403.530 jiwa sehingga dapat dikatakan bahwa telah terjadi peninggkatan penduduk yaitu sebanyak 11.027 jiwa. Dengan meningkatnya penduduk maka berakibat kepada perubahan penggunaan lahan. Berdasarkan data yang semula luas lahan sawah sebanyak 24.269 Ha pada tahun 2014 berkurang menjadi 22.856 Ha (BPS Padang Pariaman, 2015). Padang Pariaman selama 10 tahun terakhir selalu surplus beras dan untuk mendukung pemerintah Padang Pariaman yang menargetkan swasembada pangan nasional untuk itu konversi lahan sawah harus diminimalisir sehingga Padang Pariaman bisa mencapai produktivitas padi sebesar 300 ribu ton sesuai target swasembada pangan nasional tahun 2017.

Laju perubahan lahan pertanian yang semakin meningkat setiap tahunnya akan berdampak pada produksi padi di Indonesia, maka dari pada itu dibuatlah Undang- Undang Republik Indonesia Nomor 41 tahun 2009 Tentang Perlindungan Lahan Pertanian Pangan Berkelanjutan dan juga dibahas dalam PP Nomor 1 tahun 2011 Tentang Penetapan dan Alih Fungsi Lahan Pertanian Pangan Berkelanjutan. Aturan ini dibuat bertujuan untuk melindungi lahan pertanian agar tidak dialih fungsikan kebentuk lahan yang lainnya seperti lahan pemukiman, lahan perkebunan dan lahan-lahan lainnya. Sehingga dengan 
adanya undang-undang ini lahan sawah akan digunakan secara terus menerus untuk kegiatan pertanian dan dapat terselamatkan.

Kecamatan 2 x 11 Enam Lingkung merupakan kawasan yang rawan konversi. Hal ini dikarenakan wilayah Kecamatan 2 x 11 Enam lingkung dilewati oleh jalan utama Padang - Bukittinggi yang mana potensi terjadinya konversi lahan sangat tinggi. Disamping itu, salah satu nagarinya yakni Sicincin memiliki potensi pasar yang cukup potensial. Letak wilayah Kecamatan 2 x 11 Enam Lingkung yang dekat dengan pusat ibu kota Kabupaten Padang Pariaman yang merupakan daerah yang masih berkembang juga merupakan salah satu faktor tingginya tingkat rawan konversi lahan sawah di Kecamatan 2 x 11 Enam Lingkung.

Semakin pesatnya konversi lahan sawah yang terjadi di Kecamatan 2 x 11 Enam Lingkung Kabupaten Padang Pariaman mengakibatkan total areal sawah yang ada semakin sedikit. Sehingga apabila alih fungsi lahan ini dibiarkan maka, produksi beras dan pangan untuk memenuhi kebutuhan konsumsi penduduk semakin berkurang oleh sebab itu diperlukan lahan yang tetap dipertahankan sebagai areal persawahan, untuk memenuhi kebutuhan konsumsi penduduk khususnya di Kecamatan 2 x 11 Enam Lingkung Kabupaten Padang Pariaman.

\section{METODOLOGI PENELITIAN}

\section{A. Waktu dan Lokasi Penelitian}

Penelitian ini dilaksanakan di Kecamatan 2 x 11 Enam Lingkung Kabupaten Padang Pariaman dan pengolahan data dilaksanakan di Laboratorium Teknik Sumber Daya Lahan dan Air Fakultas Teknologi Pertanian Universitas Andalas pada bulan September-Oktober 2016.

\section{B. Alat dan Bahan Penelitian}

Alat yang digunakan dalam pelaksanaan penelitian ini yaitu: GPS untuk alat survei dalam pengambilan data dilapangan. Bahan sebagai pendukung proses penelitian, bahan tersebut yaitu seperti: Citra Google Spot 5, Peta Administrasi Sumatera Barat dan Kabupaten Padang Pariaman untuk mengetahui batas administrasi Sumatera Barat dan Kabupaten Padang Pariaman, Peta Administrasi Kecamatan 2 x 11 Enam Lingkung yang digunakan untuk menunjukkan sebagai target wilayah penelitian, Peta Areal Sawah Kecamatan 2 x 11 Enam Lingkung, Peta Jaringan Irigasi Kecamatan 2 x 11 Enam Lingkung, dan Peta Jaringan Jalan Kecamatan 2 x 11 Enam Lingkung.

\section{Prosedur Penelitian}

Menentukan identifikasi lahan rawan konversi di Kecamatan 2 x 11 Enam Lingkung Kabupaten Padang Pariaman digunakan metode survei lapangan dan untuk melakukan identifikasi lahan sawah yang akan dijadikan lahan pertanian yang berpotensi terjadinya konversi lahan maka lahan dikelompokan berdasarkan kriteria kualitas lahan yang sudah dilakukan (Abdurachman,2004). Setelah itu dikelompokan jenis konversi lahan (Sihaloho,2004) serta melakukan pengolahan data spasial berupa digitasi dan overlay dengan menggunakan perangkat ArcGIS 10.

Tahap selanjutnya untuk menghasilkan suatu output peta rekomendasi lahan pertanian pangan berkelanjutan rawan konversi kita memerlukan data peta dan atribut dari lahan sawah yang ada di daerah tersebut. Penelitian ini dilakukan dalam beberapa tahapan pelaksanaan penelitian. Adapun kegiatan yang akan dilakukan pada masing-masing tahapan adalah sebagai berikut:

\section{Pengumpulan Data (Input)}

Pengumpulan data untuk penelitian diantaranya pengumpulan data yang terdiri dari:

a. Data primer: data hasil survei lapangan yang berguna sebagai data untuk pengelompokan kelas kriteria kualitas lahan sawah berdasarkan parameter pengelompokan menurut Abdurachman (2004) dan kriteria jenis konversi lahan menurut Sihaloho (2004), di Kecamtan 2 x 11 Enam Lingkung Kabupaten Padang Pariaman.

b. Data sekunder: data indeks pertanaman padi sawah Kecamatan 2 x 11 Enam Lingkung untuk mengetahui kemampuan lahan dalam menanam pada semusim tanam selama satu tahun; 
data Produktivitas Padi Sawah Kecamatan 2 x 11 Enam Lingkung untuk mengetahui jumlah produktivitas lahan sawah; data Status Irigasi Kecamatan 2 x 11 Enam Lingkung untuk mengetahui status irigasi pada lahan sawah; data Luas Areal Sawah Kecamatan 2 x 11 Enam Lingkung untuk mengetahui luas lahan sawah, Tata Guna Lahan Kecamatan 2 x 11 Enam Lingkung; dan Data Rancang Tata Ruang Wilayah (RTRW) Kecamatan 2 x 11 Enam Lingkung.

\section{Pengolahan Data}

Setelah diperoleh semua data maka akan dilakukan proses pengolahan data yaitu:

1. Menginput Peta Administrasi Kabupaten Padang Pariaman ke dalam aplikasi ArcGIS 10 untuk menampilkan batas wilayah Kabupaten Padang Pariaman.

2. Menginput Peta Administrasi Kecamatan 2 x 11 Enam Lingkung untuk menampilkan wilayah penelitian.

3. Menginput peta areal lahan sawah Kecamatan 2 x 11 Enam Lingkung dan data luas lahan sawah.

4. Menginput data atribut untuk indeks pertanaman padi pada areal sawah dan jumlah produktivitas sawah tersebut.

5. Menginput peta jaringan irigasi Kecamatan 2 x 11 Enam Lingkung.

6. Menginput data status irigasi pada lahan sawah yang terdapat di Kecamatan 2 x 11 Enam Lingkung.

7. Menginputkan tata guna lahan di Kecamatan 2 x 11 Enam Lingkung.

8. Menginputkan data rancang tata ruang wilayah Kecamatan 2 x 11 Enam Lingkung.

9. Melakukan metode overlay atau tumpang susun pada peta.

10. Setelah lengkap data untuk setiap parameter dari kriteria kualitas lahan yang dijadikan indikator dalam menentukan lahan sawah rawan konversi, maka akan dikelompokkan lahan sawah tersebut menjadi 4 kelas yang telah ditetapkan yaitu Sawah Utama I, Sawah Utama II, Sawah Sekunder I, Sawah Sekunder II. Pengelompokan lahan sawah berdasarkan parameter ini merupakan pengelompokan menurut Abdurachman (2004).

11. Pengelompokan lahan sawah rawan konversi berdasarkan Sihaloho (2004). Penelitian untuk tipe konversi lahan sawah yang digunakan hanya tipe K2, K3, K7 dan K8 untuk tipe yang lain tidak digunakan karena untuk penentuannya terdapat hal yang masih bersifat abstrak dan skeptis.

\section{Analsisi Data}

\section{Analisis Kriteria Kualitas Lahan Sawah}

Hasil setelah melakukan pengolahan data setiap parameter dari kriteria kualitas lahan berdasarkan pengelompokan menurut Abdurachman (2004), yakni status irigasi, indeks penanaman dan produktivitas, didapatkan 4 pembagian sawah yaitu Sawah Utama 1, Sawah Utama II, Sawah Sekunder I, dan Sawah Sekunder II dari daerah Kecamatan 2 x 11 Enam Lingkung. Pembagian sawah ini merupakan dasar dari indentifikasi kawasan lahan sawah yang rawan konversi. Setiap pembagian lahan sawah yang ada nantinya berkemungkinan terdapat luasan lahan sawah yang rawan konversi.

\section{Analisis Data Dalam Penetapan Lahan Sawah Rawan Konversi}

Hasil setelah melakukan pengolahan peta dan data pada software ArcGIS maka akan didapatkan daerah mana di Kecamatan 2 x 11 Enam Lingkung Kabupaten Padang Pariaman yang mempunyai kawasan lahan sawah yang sesuai kriteria kawasan lahan sawah rawan konversi. Melengkapi data untuk penetapan lahan sawah rawan konversi di Kecamatan 2 x 11 Enam Lingkung Kabupaten Padang Pariaman maka akan dilakukan survei lapangan serta diskusi pada Dinas Pertanian atau Balai Penyuluhan Kecamatan yang berfungsi sebagai data tambahan yang berguna sebagai acuan untuk menetapkan lahan pertanian rawan konversi di Kecamatan 2 x 11 Enam Lingkung Kabupaten Padang Pariaman. Setelah didapatkan lahan sawah yang sesuai berdasarkan kriteria lahan rawan konversi, tahap selanjutnya yaitu pengelompokan daerah lahan sawah rawan konversi. 


\section{HASIL DAN PEMBAHASAN}

\section{A. Gambaran Umum Lokasi Penelitian}

Kecamatan 2x11 Enam Lingkung merupakan salah satu dari 17 kecamatan yang ada di Kabupaten Padang Pariaman yang terletak dekat dengan pusat ibu kota Kabupaten Padang Pariaman. Kecamatan 2x11 Enam Lingkung terletak antara 100 ${ }^{\circ} 16^{\prime} 00^{\prime \prime}$ Bujur Timur dan 0³9'00' Lintang Selatan. Luas wilayah Kecamatan 2 x 11 Enam Lingkung mencapai $36,25 \mathrm{~km}^{2}$. Kondisi topografi wilayah Kecamatan 2 x 11 Enam Lingkung yakni bergelombang sampai ke deretan Bukit Barisan dengan ketinggian $\pm 25-1000$ meter di atas permukaan laut.

Kecamatan 2x11 Enam Lingkung memiliki batas-batas wilayah sebagai berikut:

1. Sebelah Utara berbatasan dengan Kecamatan Patamuan dan Kecamatan 2x11 Kayu Tanam;

2. Sebelah Selatan berbatasan dengan Kecamatan Enam Lingkung;

3. Sebelah Barat berbatasan dengan Kecamatan VII Koto;

4. Sebelah Timur berbatasan dengan Kecamatan 2x11 Kayu Tanam.

Kecamatan 2x11 Enam Lingkung terdapat 3 (Tiga) nagari yaitu Nagari Lubuk Pandan yang memiliki 5 korong dengan luas daerah $6,84 \mathrm{~km}^{2}$, Nagari Sicincin yang memiliki 4 korong dengan besar luas daerah 21,80 $\mathrm{km}^{2}$, dan terakhir Nagari Sungai Asam yang memiliki 3 korong dengan luas daerah $7,61 \mathrm{~km}^{2}$.

\section{B. Lahan Sawah Kecamatan 2x11 Enam Lingkung}

Kecamatan 2x11 Enam Lingkung merupakan kecamatan yang 25,16\% wilayahnya berupa lahan sawah (2x11 Enam Lingkung dalam Angka 2015). Lahan sawah Kecamatan 2x11 Enam Lingkung banyak terletak di pinggir jalan utama Padang-Bukittinggi yang merupakan jalan padat lalu lintas yang mana nantinya lahan sawah ini sangat rawan konversi. Berdasarkan hasil dari pengolahan data spasial dan citra Kecamatan 2x11 Enam Lingkung yang telah dilakukan diperoleh luas areal sawah untuk Kecamatan 2x11 Enam Lingkung Tahun 2016 yaitu sebesar 886,66 Ha dan dapat dilihat pada Tabel 1.

Tabel 1. Luas Areal Sawah Kecamatan 2x11 Enam lingkung per Nagari

\begin{tabular}{llc}
\hline No. & Nama Nagari & Luas Areal Sawah (Ha) \\
\hline 1 & Lubuk Pandan & 346,84 \\
2 & Sicincin & 320,28 \\
3 & Sungai Asam & 219,54 \\
\hline & Luas Total & 886,66 \\
\hline
\end{tabular}

Sumber: Hasil Analisis (2016)

\section{Penentuan Kriteria Kualitas Lahan Sawah}

Menurut Abdurachman et al. (2004), menentukan kriteria kualitas lahan sawah diperlukan parameter-parameter yang perlu diperhatikan seperti status irigasi, indeks pertanaman padi, dan kualitas sumberdaya tanah atau produktivitas.

\section{Status Irigasi}

Status irigasi dibedakan dalam empat kelas, yakni lahan sawah beririgasi teknis, irigasi semiteknis, irigasi sederhana, dan lahan sawah tadah hujan menurut Badan Pertahanan Nasional (1999) dalam Fendri (2012). Dari pengelompokkan tersebut diperoleh status irigasi lahan sawah di Kecamatan 2x11 Enam Lingkung. Status Irigasi lahan sawah Kecamatan 2x11 Enam Lingkung dapat dilihat pada Tabel 2. 
Tabel 2.Status Irigasi Lahan Sawah Kecamatan 2x11 Enam Lingkung

\begin{tabular}{lll}
\hline Status Irigasi & Ada/Tidak & Nama Irigasi \\
\hline Irigasi Teknis & Ada & Sicaung, Ladang Laweh \\
Irigasi Semiteknis & Ada & Ampang Sipinang, Sicaung \\
Irigasi Sederhana & Ada & Banda Situntun, Banda Sigabua, Sungai Tampiun, \\
& & Batang Tapakih, Batang Kapecong, Sungai Abu \\
Tadah Hujan & Ada & - \\
\hline Suda
\end{tabular}

Berdasarkan tabel diatas dapat dilihat bahwa di Kecamatan 2x11 Enam Lingkung memiliki status irigasi berupa irigasi teknis, irigasi semiteknis, irigasi sederhana, dan tadah hujan. Berdasarkan hasil survey lapangan dan hasil pengolahan data pada lahan sawah di Kecamatan 2x11 Enam Lingkung didapatkan pengelompokkan lahan sawah berdasarkan status irigasinya beserta luas lahan sawah yang didapatkan. Adapun luas lahan sawah Kecamatan 2x11 Enam Lingkung berdasarkan status irigasi dapat dilihat pada Tabel 3 .

Tabel 3. Luas Lahan Sawah Kecamatan 2x11 Enam Lingkung Berdasarkan Status Irigasi

\begin{tabular}{lcc}
\hline Status Irigasi & Luas Areal Sawah (Ha) & Persentase $(\boldsymbol{\%})$ \\
\hline Teknis & 81,82 & 9,23 \\
Semi Teknis & 469,16 & 52,91 \\
Sederhana & 266,05 & 30,01 \\
Tadah Hujan & 69,63 & 7,85 \\
\hline Total & $\mathbf{8 8 6 , 6 6}$ & $\mathbf{1 0 0}$ \\
\hline
\end{tabular}

Sumber: Hasil Analisis (2016)

Berdasarkan data hasil analisis status irigasi pada lahan sawah di Kecamatan 2x11 Enam Lingkung, didapatkankan bahwa lahan sawah di Kecamatan 2x11 Enam Lingkung sebagian besar telah dialiri dengan irigasi semiteknis sebanyak 52,91\% dan teknis hanya 9,23\%. Besar luas lahan sawah yang dialiri irigasi semiteknis ini juga hampir sama dengan data dari BPS Padang Pariaman sebesar 450 Ha. Banyak lahan sawah yang dialiri irigasi semiteknis dikarenakan adanya irigasi Sicaung yang berasal dari sungai Batang Anai. Disamping itu, untuk yang dialiri oleh irigasi sederhana masih cukup banyak yaitu sebesar 266,05 Ha atau 30,01\% dari total luas sawah. Selain itu, untuk lahan sawah yang masih tadah hujan luas lahanya sebesar 69,63 Ha atau 7,85\% dari luas total lahan sawah di Kecamatan 2x11 Enam Lingkung. Berdasarkan hasil analisis, disetiap nagari di Kecamatan 2x11 Enam Lingkung memiliki lahan sawah yang beririgasi semiteknis. Sementara itu, untuk lahan sawah yang masih tadah hujan berada di Nagari Sicincin dan Nagari Lubuk Pandan serta sedikit yang berada di Nagari Sungai Asam.

\section{Indeks Pertanaman (IP)}

Kemampuan tanam untuk setiap lahan padi sawah berbeda-beda, hal ini disebabkan karena ada beberapa yang mempengaruhi seperti tingkat kesuburan tanah, ketersedian air pada lahan dan faktor lainnya. Indeks pertanaman merupakan jumlah dari penanaman areal sawah dalam satu tahun. Indeks Pertanaman (IP) dibedakan atas dua kelas, yakni IP $\geq 2$ dan IP $\leq 2$ kali tanam setahun. Penggolongan IP dilakukan untuk menentukan bahwa sawah irigasi sebagian besar dapat ditanami padi dua kali atau lebih dalam setahun. Sawah yang mempunyai IP $<2$ kali tanam dalam setahun umumnya merupakan sawah tadah hujan atau sebagian sawah irigasi yang hanya dapat ditanami padi sekali setahun karena ketersediaan air tidak mencukupi.

Lahan sawah dengan indeks pertanaman kecil dari 2 kali setahun umumnya ialah lahan sawah tadah hujan dengan tingkat produktivitas yang tidak terlalu besar. Pada kategori tingkat kualitas lahan, lahan yang nilai indeks pertanamannya kecil dan tadah hujan termasuk dalam kualitas lahan Sawah 
Sekunder I dan Sawah Sekunder II. Maka dari itu, kualitas lahan ini termasuk dalam lahan sawah yang berkemungkinan besar rawan akan konversi lahan.

Setelah melakuan kegiatan survei di lapangan serta informasi yang diberikan dari Balai Penyuluh Pertanian (BPK), di dapatkan bahwa indeks pertanaman di Kecamatan 2x11 Enam Lingkung hampir keseluruhannya memiliki indeks pertanaman 2 kali tanam dalam setahun, baik itu lahan sawah dengan irigasi teknis, semiteknis, dan beberapa yang irigasi sederhana. Disamping itu, ada juga lahan sawah di Kecamatan 2x11 Enam Lingkung yang memiliki indeks pertanaman 1,5 kali atau 3 kali dalam 2 tahun. Indeks Pertanaman yang 1,5 kali secara keseluruhan merupakan lahan sawah tadah hujan dengan sumber air untuk mengairi lahan tergantung dari tingkat curah hujan yang terjadi pada daerah tersebut. Adapun indeks pertanaman lahan sawah berdasarkan hasil analisis dapat dilihat pada Tabel 4.

Tabel 4. Indeks Pertanaman (IP) Lahan Sawah Kecamatan 2x11 Enam Lingkung

\begin{tabular}{lcc}
\hline Indeks Pertanaman & Qgn n $\mathbf{~}$ & Persentase (\%) \\
\hline 2 kali & 830,84 & 93,71 \\
$1,5 \mathrm{kali}$ & 55,81 & 6,29 \\
\hline Total & 886,66 & 100 \\
\hline Sumber: Hasil Analisis (2016) & &
\end{tabular}

Berdasarkan data diatas dapat dilihat bahwa lahan sawah di Kecamatan 2x11 Enam Lingkung hampir seluruhnya memiliki indeks pertanaman 2 kali dengan luas areal sawah 830,84 Ha atau 93,71 $\%$ dari total luas lahan sawah yang ada. Disamping itu, lahan sawah dengan indeks pertanaman 1,5 kali sebesar 55,81 Ha atau hanya sekitar 6,29\% dari total luas lahan sawah yang ada. Lahan sawah dengan indeks pertanaman rendah berkemungkinan besar terjadi kegiatan konversi lahan dikarenakan lahan tersebut termasuk lahan kurang produktif.

\section{Produktivitas}

Menentukan lahan rawan konversi, produktivitas termasuk indikator yang paling penting. Tingkat besar atau kecilnya produktivitas lahan sawah menentukan tingkat konversi lahan sawah tersebut. Kecilnya produktivitas merupakan salah satu penyebab terjadinya konversi lahan serta termasuk tipe konversi lahan sistematik berpola enclave, K2 (Sihaloho, 2004). Besarnya produktivitas lahan sawah di Kecamatan 2x11 Enam Lingkung dapat dilihat pada Tabel 5.

Tabel 5. Produktivitas Lahan Sawah Kecamatan 2x11 Enam Lingkung

\begin{tabular}{llcc}
\hline Luas Tanam (Ha) & Luas Panen (Ha) & $\begin{array}{c}\text { Produksi Lahan Sawah } \\
\text { (Ton) }\end{array}$ & Produktivitas(Ton/Ha) \\
\hline 1688 & 1797 & 9524 & 5,30 \\
\hline
\end{tabular}

Sumber: Dinas Pertanian, Peternakan, dan Kehutanan Kabupaten Padang Pariaman (2015)

Menentukan produktivitas suatu lahan bisa didapat dari pembagian antara produksi lahan dengan luas panen pada suatu lahan pada satu tahun. Berdasarkan tabel diatas produktivitas rata-rata lahan sawah di Kecamatan 2x11 Enam Lingkung sebesar 5,3 Ton/Ha. Akan tetapi, pada saat survei ada beberapa lahan yang memiliki tingkat produktivitas kecil. Untuk itu, dalam penentuan kualitas lahan dibagi dalam dua kriteria yakni produktivitas $\leq 4,50 \mathrm{Ton} / \mathrm{Ha}$ atau $\geq 4,50 \mathrm{Ton} / \mathrm{Ha}$. Adapun produktivitas lahan sawah di Kecamatan 2x11 Enam Lingkung berdasarkan hasil analisis bisa dilihat pada Tabel 6 .

Tabel 6. Produktivitas Lahan Sawah Berdasarkan Hasil Analisis

\begin{tabular}{lll}
\hline Produktivitas (Ton/Ha) & Luas Areal Sawah $\mathbf{( H a )}$ & Persentase $\mathbf{( \% )}$ \\
\hline$\geq 4,50$ & 602,85 & 67,99 \\
$\leq 4,50$ & 283,80 & 32,01 \\
\hline Total & 886,66 & 100 \\
\hline
\end{tabular}

Sumber: Hasil Analisis (2016) 
Berdasarkan data yang didapatkan bahwa produktivitas di Kecamatan 2x11 Enam Lingkung yang $\geq 4,50 \mathrm{Ton} / \mathrm{Ha}$ memiliki luas areal sawah cukup besar yakni $602,85 \mathrm{Ha}$ atau hamper $67,99 \%$ dari total luas areal sawah yang ada. Hal ini disebabkan karena banyak areal sawah telah dialiri oleh irigasi, baik teknis, semiteknis, maupun sederhana. Walaupun di lapangan ada beberapa lahan beririgasi dengan nilai produktivitasnya masih kurang dari 4,5 Ton/Ha. Kemudian dari pada itu, lahan sawah yang memiliki produktivitas $\leq 4,50 \mathrm{Ton} / \mathrm{Ha}$ memilki luas areal 283,80 Ha atau 32,01 \% dari total luas lahan yang ada. Sebagian besar lahan sawah dengan produktivitas kurang dari 4,5 Ton/Ha ialah sawah tadah hujan dengan kebutuhan air masih tergantung dari tingkat curah hujan pada daerah tersebut.

\section{Kelas Lahan Sawah}

Penentuan kelas lahan sawah berdasarkan parameter-parameter berupa jenis irigasi, indeks pertanaman serta produktivitas lahan maka pengelompokkan kelas lahan sawah di Kecamatan 2x11 Enam Lingkung dikelompokkan menjadi 4 kelas lahan sawah yang mana empat kelas lahan sawah tersebut yaitu Sawah Utama I, Sawah Utama II, Sawah Sekunder I, Sawah Sekunder II. Adapun pengelompokkan kelas lahan sawah yang didapatkan dari hasil analisis dapat dilihat pada Tabel 7.

Tabel 7. Kelas Lahan Sawah di Kecamatan 2x11 Enam Lingkung

\begin{tabular}{lll}
\hline Kelas Lahan Sawah & Luas Areal Sawah (Ha) & Persentase (\%) \\
\hline Sawah Utama I & 408,01 & 46,02 \\
Sawah Utama II & 337,82 & 38,10 \\
Sawah Sekunder I & 85,02 & 9,59 \\
Sawah Sekunder II & 55,81 & 6,29 \\
\hline Total & 886,66 & 100 \\
\hline
\end{tabular}

Sumber: Hasil Analisis (2016)

Berdasarkan data, didapatkan luas areal sawah yang termasuk dalam kelas lahan sawah utama I sebesar 408,01 Ha atau 46,02 \% dari total luas lahan. Hampir setengah lahan sawah dari total luas lahan sawah di Kecamatan 2x11 Enam Lingkung termasuk dalam sawah utama 1, hal ini disebabkan karena adanya irigasi "sicaung" yang bersumber dari sungai Batang Anai yang mengairi lahan sawah yang ada di Kecamatan 2x11 Enam Lingkung sehingga nilai IP dan produktivitasnya tinggi. Selanjutnya, lahan sawah yang termasuk dalam sawah utama II ada sekitar 337,82 Ha $(38,10 \%$ dari total luas lahan), sebagain besar merupakan lahan sawah beririgasi semi teknis dan tradisional dan memiliki produktivitas lebih dari 4,5 Ton/Ha serta memiliki indeks pertanaman 2 kali dalam setahun walaupun beberapa lahan sawah memiliki produktivitas kurang dari 4,5 Ton/Ha. Kemudian dari pada itu, lahan sawah yang termasuk sawah sekunder I ada 85,02 Ha (9,59 \% dari total luas lahan) dan lahan yang termasuk sawah sekunder II ada 55,81 Ha (6,29\% dari total luas lahan). Lahan yang termasuk dalam kelas sawah sekunder II termasuk kedalam lahan sawah kurang produktif karena keseluruhannya merupakan lahan sawah tadah hujan dengan produktivitas dan IP yang dibawah rata-rata karena itulah lahan sawah yang termasuk kelas ini merupakan lahan sawah rawan konversi lahan.

\section{E. Lahan Sawah Rawan Konversi}

Penentuan lahan sawah rawan konversi dikelompokkan dalam beberapa tipe konversi lahan, sebagaimana telah tipologikan oleh Sihalaho (2004) bahwa ada 8 tipe lahan konversi lahan. Tipe konversi lahan yang digunakan dalam penelitian ini ialah tipe $\mathrm{K} 2, \mathrm{~K} 3, \mathrm{~K} 7$, dan $\mathrm{K} 8$, sedangkan untuk tipe konversi lainnya tidak digunakan karena penyebab terjadinya konversi masih bersifat abstrak dan skeptis dalam penentuannya serta perlu survei lebih mendalam kepada pelaku konversi lahan atau pemiliki lahan sawah. Luasan lahan sawah rawan konversi beserta tipe konversi serta luas masingmasing kelas lahan sawah yang terkena lahan rawan konversi bisa diliat pada Tabel 8 . 
Tabel 8. Luas Lahan Sawah Rawan Konversi di Kecamatan 2x11 Enam Lingkung

\begin{tabular}{ccccccc}
\hline \multirow{2}{*}{$\begin{array}{c}\text { Tipe Konversi } \\
\text { Lahan (Ha) }\end{array}$} & \multicolumn{5}{c}{ Kelas Lahan Sawah (Ha) } & \multicolumn{2}{c}{ Tokasi } \\
\cline { 2 - 5 } & $\begin{array}{c}\text { Sawah } \\
\text { Utama I }\end{array}$ & $\begin{array}{c}\text { Sawah } \\
\text { Utama II }\end{array}$ & $\begin{array}{c}\text { Sawah } \\
\text { Sekunder I }\end{array}$ & $\begin{array}{c}\text { Sawah } \\
\text { Sekunder II }\end{array}$ & \multicolumn{2}{c}{$\begin{array}{c}\text { Total } \\
\text { Lahan* }\end{array}$} \\
\hline K1 & - & - & - & - & - & - \\
K2 & - & - & - & 55,81 & 55,81 & LP, SC \\
K3 & 26,09 & 25,34 & 4,22 & - & 55.65 & LP, SC, SA \\
K4 & - & - & - & - & - & - \\
K5 & - & - & - & - & - & - \\
K6 & - & - & - & - & - & - \\
K7 & 0,64 & 1,58 & - & - & 2,22 & LP, SC, SA \\
K8 & 55,98 & 16,16 & - & - & 72,15 & LP, SC, SA \\
\hline Total & 82,71 & 43,09 & 4,22 & 55,81 & $\mathbf{1 8 5 . 8 3}$ & \\
\hline
\end{tabular}

*) LP = Lubuk Pandan, SC = Sicincin, SA = Sungai Asam

Sumber: Hasil Analisis (2016)

Berdasarkan hasil analisis didapatkan luasan lahan sawah yang termasuk tipe konversi K2 (konversi yang disebabkan oleh lahan kurang produktif) sebesar 55,81 Ha. Lahan sawah yang terkena tipe konversi K2 merupakan lahan sawah dengan kelas Sawah Sekunder II dengan kualitas lahan rendah, seperti tidak ada irigasi (tadah hujan), nilai indeks pertanaman kurang dari 2 kali dalam setahun dan produktivitas kurang dari 4,5 Ton/Ha. Selanjutnya, lahan sawah yang terkena tipe konversi K3 (konversi yang disebabkan pertumbuhan penduduk) sebesar 55,65 Ha, ada beberapa kelas lahan sawah yang terkena rawan konversi tipe K3 diantaranya Sawah Utama I, Sawah Utama II, dan Sawah Sekunder I berturut-turut luas lahan sawah yang terkena 26,09 Ha, 25,34 Ha dan 4,22 Ha. Pengambilan lahan sawah yang termasuk tipe konversi K3 ialah lahan sawah dekat dengan pemukiman/perkampungan masyarakat.

Selanjutnya, lahan sawah yang termasuk kedalam tipe konversi K7 (konversi yang disebabkan faktor khusus yang diperuntukkan) hanya sekitar 2,22 Ha. Faktor khusus yang diperuntukan umumnya untuk perluasan daerah perkantoran, sekolah serta fasilitas umum di Kecamatan 2x11 Enam Lingkung. Kemudian dari pada itu, lahan sawah yang termasuk tipe konversi K8 (konversi yang diakibatkan lahan dekat jalan utama, provinsi, nasioal) memiliki luas terbesar yakni $72.15 \mathrm{Ha}$. Hampir semua lahan sawah yang termasuk tipe konversi K8 merupakan lahan Sawah Utama I (55,98 Ha) karena lahan sawah di Kecamatan 2x11 Enam Lingkung dengan irigasi teknis dan semi teknis umumnya berada di dekat jalan. Penentuan lahan sawah rawan konversi tipe K8 dengan cara mengambil pembebasan lahan sawah 100 meter dari kiri-kanan jalan sesuai dengan UU RI No. 41 tahun 2009 tentang Perlindungan Lahan Pertanian Pangan Berkelanjutan.

Pengaruh konversi lahan sawah akan berdampak negatif pada produksi padi di Kecamatan 2x11 Enam Lingkung. Lahan sawah yang terkena konversi akan mengurangi produksi padi karena lahan sawah tersebut sudah dialih fungsikan menjadi non-pertanian.

Pada Tabel 9, dapat dilihat luas lahan yang terkena rawan konversi sebesar 185,83 Ha, dengan luas lahan sawah rawan konversi sebesar ini dan apabila kiranya akan dialihfungsikan dapat diprediksi produksi padi di Kecamatan 2x11 Enam Lingkung akan berkurang sebesar $\pm 1405,99$ Ton/Tahun.

Kecamatan 2x11 Enam Lingkung dilewati oleh jalan utama Padang-Bukittinggi yang padat lalu lintas, sehingga lahan sawah yang berada pada daerah dekat jalan sangat rawan konversi ke nonpertanian. Disamping itu, pertumbuhan penduduk yang meningkat berbanding lurus dengan konversi lahan sawah untuk dijadikan sebagai pemukiman penduduk. Berdasarkan hasil analisis besar luas Sawah Utama I dan Sawah Utama II terkena rawan konversi sebesar 82,71 Ha dan 43,09 Ha, untuk dua kelas lahan ini sebaiknya konversi lahan dapat diperkecil dan lebih baiknya lagi jangan sampai terkonversi karena Sawah Utama I dan II merupakan lahan sawah dengan kualitas yang baik sehingga nantinya tidak menurunkan hasil produksi beras di Kecamatan 2x11 Enam Lingkung. 
Tabel 9. Pengaruh Konversi Lahan Terhadap Produksi Padi

\begin{tabular}{ccccc}
\hline $\begin{array}{c}\text { Kriteria } \\
\text { Konversi }\end{array}$ & Luas (Ha) & $\begin{array}{c}\text { Produktivitas } \\
\text { (Ton/Ha) }\end{array}$ & $\begin{array}{c}\text { Indeks } \\
\text { Pertanaman }\end{array}$ & $\begin{array}{c}\text { Produksi Padi } \\
\text { (Ton/Thn) }\end{array}$ \\
\hline K1 & - & - & - & - \\
K2 & 55.81 & 3 & 1.5 & 251.15 \\
K3 & 55.65 & 4.27 & 2 & 474.71 \\
K4 & - & - & - & - \\
K5 & - & - & - & - \\
K6 & - & - & - & - \\
K7 & 2.22 & 4.57 & 2 & 20.30 \\
K8 & 72.15 & 4.57 & 2 & 659.83 \\
Total & $\mathbf{1 8 5 . 8 3}$ & - & - & $\mathbf{1 4 0 5 . 9 9}$ \\
\hline
\end{tabular}

Sumber: Hasil Analisis (2016)

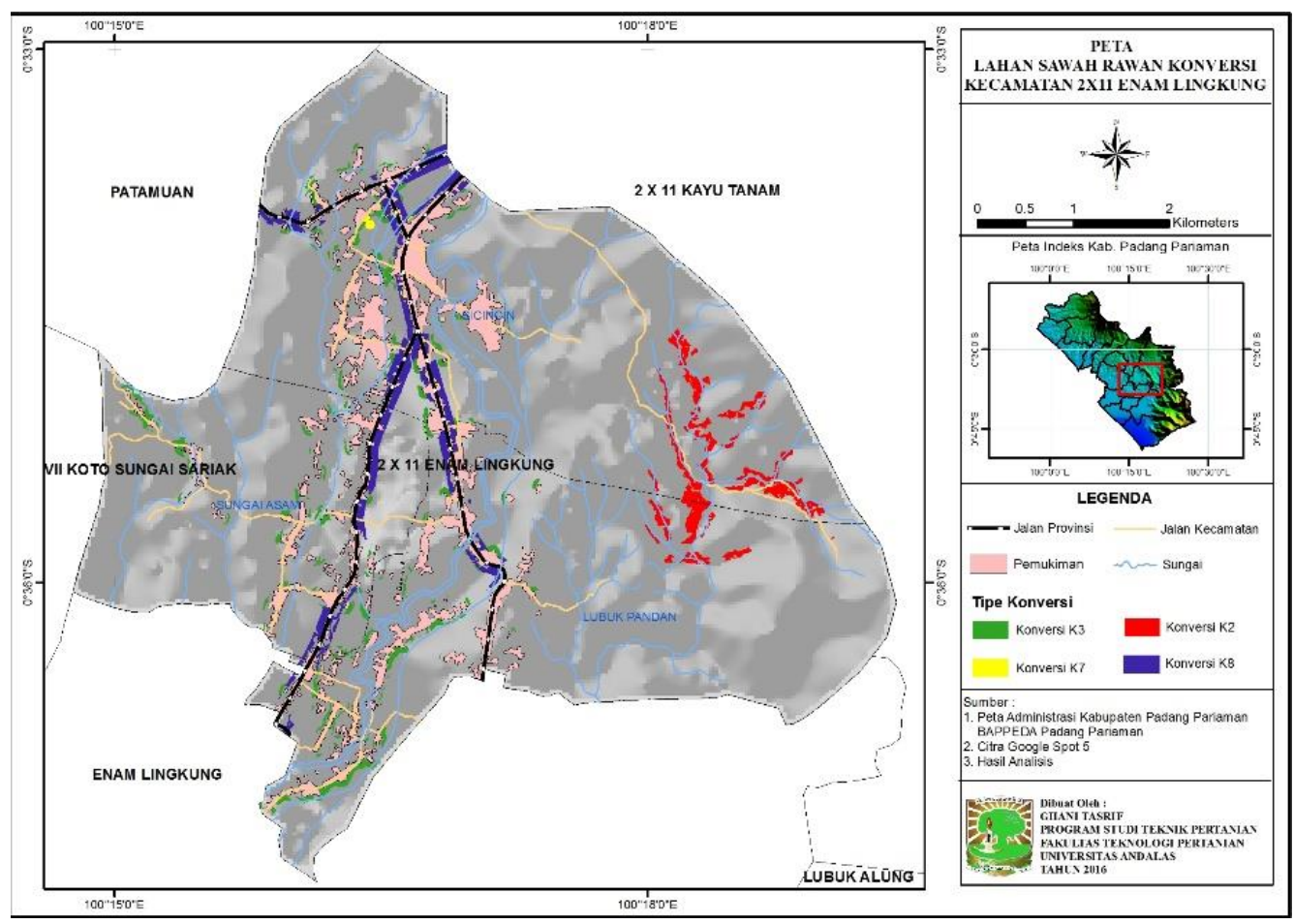

Gambar 1. Peta Lahan Sawah Rawan Konversi Kecamatan 2x11 Enam Lingkung

\section{KESIMPULAN}

Berdasarkan hasil penelitian yang telah dilakukan maka lahan sawah rawan konversi di Kecamatan 2x11 Enam Lingkung didapatkan sebesar 185,83 Ha dengan empat tipe konversi yakni tipe konversi K2 (konversi yang disebabkan lahan kurang produktif), K3 (konversi yang disebabkan pertumbuhan penduduk), K7 (konversi yang disebabkan faktor yang diperuntukkan), dan K8 (konversi yang disebabkan kawasan dekat jalan utama, provinsi, nasional). Luas lahan terbesar lahan sawah rawan konversi terbesar terdapat pada tipe konversi K8 dengan luas lahan sawah 72,15 Ha dan terkecil pada tipe konversi K7 sebesar 2,22 Ha.Prediksi kehilangan produksi padi di Kecamatan 2x11 Enam Lingkung jika semua lahan sawah yang rawan konversi mengalami konversi lahan sebesar $\pm 1405,99$ Ton/Tahun. 


\section{DAFTAR PUSTAKA}

Abdurachman, A., Wahyunto, dan R. Shofiyati. 2004. Gagasan Pengendalian Konversi Lahan Sawah Dalam Rangka Peninkatan Ketahanan Pangan Nasional. Prosiding Seminar Multifungsi Pertanian dan Konservasi Sumberdaya Lahan. Bogor, 13 Desember 2003.

BPS Kabupaten Padang Pariaman. 2015. Padang Pariaman dalam angka2015.

Fendri, J. 2012. Evaluasi Spasial Lahan Pangan Berkelanjutan di Kota Padang [Skripsi]. Padang (ID). Fakultas Teknologi Pertanian Universitas Andalas.

PP Nomor 1 Tahun 2011 tentang Penetapan dan Alih Fungsi Lahan Pertanian Pangan Berkelanjutan. Sihaloho, Martua.2004.Konversi Lahan Pertanian dan Perubahan Struktur Agraria.[Tesis] Fakultas Pascasarjana.Bogor(ID).Institut Pertanian Bogor

UU RI Nomor 41 Tahun 2009 Tentang Perlindungan Lahan Petanian Berkelanjutan 